\title{
Beauty and Artistic Value
}

\author{
Annelies Monseré and Bart Vandenabeele
}

\begin{abstract}
This paper defuses anti-beauty and pro-beauty arguments by offering a more adequate account of artistic beauty. We argue that neither beauty, nor extra-beauty concerns should be discarded as values of art. Therefore, we distinguish artistic beauty from both aesthetic excellence and beauty as such. Hence, when we judge that an artwork is aesthetically valuable, it does not automatically follow that the artwork is beautiful. If artistic beauty is equated with aesthetic excellence then the notion of beauty is stretched almost beyond recognition or many non-beautiful artworks are denied aesthetic value. Moreover, the beauty of an artwork does not plainly coincide with beauty per se. Many artworks can be perceived as beautiful, but this does not automatically entail that the perceived beauty is an aesthetic merit of the artwork, i.e. that it contributes to the artwork's artistic value. Furthermore, if the beauty of an artwork contradicts or diminishes other properties of an artwork, the artwork's beauty counts as an aesthetic demerit. Properly drawing these distinctions is of paramount importance for the following reasons. (1) These distinctions allow us to assign aesthetic excellence to non-beautiful art. There is no need to include non-beautiful art within the realm of beauty in order to judge such artworks as aesthetically valuable. (2) These distinctions help clarifying why not all beauty in art counts as artistic beauty. Beauty that is incidental or contradicts the aims or content of the artwork is not artistic beauty. Thus, surface beauty in art does not necessarily imply artistic beauty or aesthetic merit. (3) Artistic beauty is not the mere representation of a beautiful thing. What is ugly in nature can be beautiful in art. We conclude that these distinctions are useful for assessing the role of beauty and aesthetics in art.
\end{abstract}

Key Words: Art, philosophy, aesthetics, artistic value, aesthetic value, artistic beauty, Nick Zangwill, Arthur Danto.

$* * * * *$

\section{Introduction}

Several contemporary philosophers of art argue that appreciating an artwork merely in terms of whether it is beautiful or not ignores important political, conceptual and social concerns which the artist intended to put forward. ${ }^{1}$ So-called beauty theories of art, however, claim that the artistic value of all art resides in its being beautiful: beauty constitutes the essence of art. ${ }^{2}$

This paper will defuse anti-beauty and pro-beauty arguments by offering a more adequate account of artistic beauty. We will argue that neither beauty, nor extra-beauty concerns should be discarded as values of art. Therefore, we will 
distinguish artistic beauty from both aesthetic excellence and beauty as such. Hence, when we judge that an artwork is aesthetically valuable, it does not automatically follow that the artwork is beautiful. If artistic beauty is equated with aesthetic excellence then the notion of beauty is stretched almost beyond recognition or many non-beautiful artworks are denied aesthetic value. Moreover, the beauty of an artwork does not plainly coincide with beauty per se. Many artworks can be perceived as beautiful, but this does not automatically entail that the perceived beauty is an aesthetic merit of the artwork, i.e. that it contributes to the artwork's artistic value. Furthermore, if the beauty of an artwork contradicts or diminishes other properties of an artwork, the artwork's beauty counts as an aesthetic demerit. Consequently, we will argue that artistic beauty is not purely formal beauty. To sum up, this paper aims to distinguish between (1) artistic beauty and aesthetic value and between (2) artistic beauty and other kinds of beauty in order to restore the value of beauty in art. Because of the failure to make these distinctions, beauty was marginalized or all other relevant aesthetic and artistic considerations were excluded from the appreciation of art. Whatever the value of beauty might be in life, beauty is a historically important, but not a necessary artistic value.

\section{Beauty and Aesthetic Value}

In the first part of this paper, we will argue that not all aesthetic values of an artwork can be reduced to beauty. Consequently, we will challenge theories of art that claim that beauty constitutes the core of an artwork's value. In his book The Metaphysics of Beauty, Nick Zangwill equates judgments of beauty with 'judgments of aesthetic value'. 'Beauty', according to Zangwill, is not one aesthetic property amongst many others, but rather corresponds to a verdictive aesthetic judgment, while other aesthetic properties correspond to substantive aesthetic judgments. Verdictive aesthetic judgments concern the aesthetic merit of things. To claim things are dainty, dumpy, graceful or garish are substantive aesthetic judgments. ${ }^{4}$ These pick out properties that determine aesthetic merit or beauty. ${ }^{5}$ Substantive aesthetic properties do not necessarily imply a positive aesthetic judgment, as they do not necessarily have evaluative content. Indeed, when we dislike Karel Appel's 'Flowers and Animals' for its garishness, one might reasonably object that while the artwork is garish, in this case garishness counts as an aesthetic merit. Describing a work of art as garish can justify a positive as well as a negative aesthetic judgment, depending on the context in which the aesthetic property garishness is operative. Garishness is not necessarily good or bad in itself. Still, the substantive description stands: we all agree that 'Flowers and Animals' is a garish painting. Correspondingly, although an aesthetic property as such is perceived as an aesthetic merit, it can be rejected as an aesthetic merit of the artwork under consideration if the aesthetic property contradicts the artwork's other properties. According to Zangwill, judging that an artwork is beautiful, 
however, does imply that it is a good, i.e. an aesthetically valuable artwork: beauty always coincides with aesthetic merit and is in itself necessarily good.

In language and in traditional beauty theories, beauty is associated with harmony, balance and pleasure. The claim that all good art is beautiful attenuates the notion of beauty to the point of vanishing. Much of Philip Guston's later work is a case in point. His work has obvious substantive aesthetic properties that determine the artwork's aesthetic merit, such as expressiveness and power. Still, to claim that his highly disturbing paintings are beautiful is inadequate, as they are neither balanced and harmonious, nor do they have the apparent intention to please the audience. Further, equating artistic beauty with aesthetic value also urges us to appreciate all works of art for their beauty, while this often contradicts the aims of the artist. Arthur Danto rightly argues that beauty is an incidental attribute in most of the world's artistic cultures and many artworks are beautiful as objects, more so than as works of art. $^{6}$ At any rate, it can be claimed that beauty is often not the main focal point of the artwork, but plays the minor role of drawing attention to the object as such. Much avant-garde art even had the specific aim of not being beautiful. Dada art tried to address the inhumanities of the First World War and wanted to 'assassinate' beauty. In a similar vein Philip Guston claimed that the world as it is does not deserve beauty. ${ }^{7}$ Thus the products of Dada and of other $20^{\text {th }}$ century artists who made statements against beautifying the world, are misperceived if perceived as beautiful. ${ }^{8}$ Examples like these show that to claim that all aesthetic value should be reduced to 'beauty' is downright confusing.

Now, while the above-mentioned artworks should not be called beautiful, they should not necessarily be denied aesthetic value. Non-beautiful artworks can be appreciated as aesthetically valuable, i.e. they can possess other aesthetic qualities besides beauty. Beauty must be seen as one aesthetic property among many others. Hence, beauty can also be considered a substantive aesthetic property: this is how it is used in language and it is in line with traditional beauty theories. Moreover, the question arises whether beauty always necessarily counts as an aesthetic merit of an artwork, even if it will often so count. It is to this issue that we will now turn.

\section{Beauty and Artistic Value}

Zangwill rightly notes that some substantive aesthetic features mostly tend towards a positive evaluation while others mostly tend towards a negative one. Indeed, gracefulness mostly implies positive aesthetic merit, while ugliness will often induce a negative aesthetic judgment. In what follows, we argue, however, that, in the context of art, no substantive feature always works in one evaluative direction, i.e. even the beauty of an artwork can count as an aesthetic demerit or a marginal aesthetic merit. As aesthetic properties are internally connected to all other artistic properties of a work, it can be a matter of critique that an artwork is graceful, elegant or beautiful when it is inappropriate for it to be so. ${ }^{9}$ For example, beauty can distract us from moral and cognitive features of an artwork. Sabastao 
Salgado's photographs of human suffering are a case in point. It is a matter of debate amongst art critics and social scholars whether we can present as beautiful what calls for indignation. ${ }^{10}$

The beauty of an artwork is an aesthetic merit of the artwork, only if the artwork's beauty adds up to or is part of the artwork's artistic value. Artistic beauty is a kind of beauty that matches the concept of the artwork in question. Aesthetic properties take part in a judgment on the artistic value of an artwork only if they are relevant for the artwork. Graham McFee rightly argues that:

one's calling a painting, say, gaudy amounts to something different when one recognizes that the painting $i s$ an artwork from what it amounts to when one mistook the gaudy object for, say wallpaper. ${ }^{11}$

Therefore, taking an artwork for a merely aesthetic object is misperceiving it. Artistic appreciation, contrary to mere aesthetic appreciation, locates the artwork in question in the history and traditions of artmaking and art-appreciating. ${ }^{12}$ That is not to say that one cannot value an artwork merely for its (perceptual) aesthetic merits.

[...] of course one might value an art-object (say, a painting) as one valued wallpaper: both are attractive wall-coverings. But when I do this for the artwork, I am not continuing to regard it as an artwork, since this is not consistent with so regarding it. ${ }^{13}$

Thus, what is beautiful in art does not amount to the same as what is beautiful in non-art. In some cases, the perceptible aesthetic properties that an artwork has, are irrelevant to the appreciation of the artwork as an artwork. A classic example where beauty appreciation in an artwork is out of place is Duchamp's canonical work Fountain: to claim it is beautiful is to miss the point of the artwork. Still, there have been voices that claimed that the artwork can be appreciated for its beautiful surface. George Dickie wondered: 'Why cannot the ordinary qualities of Fountain, - its gleaming white surface, the depth revealed when it reflects images of surrounding objects, its pleasing oval shape - be appreciated? ${ }^{14}$ Well, perhaps they can, but to appreciate Fountain for its perceptual properties is to miss the point of the artistic endeavor entirely. The beauty that the object might, controversially, have, does not necessarily have any bearing on the aesthetic merit of the artwork as such. The appreciation of such artworks does not depend on their perceptual properties. ${ }^{15}$ Even if we acknowledge that art can have non-perceptual aesthetic properties, it is highly unclear how the wit, the boldness and the impudence of the artwork could be identified with beauty. Such works of art are not artistically beautiful. Now, many artworks are unjustly granted artistic beauty, while they are only incidentally beautiful or not beautiful at all. Yet, some artworks 
that do possess artistic beauty, are not called beautiful, because, again, the distinction between natural, human and artistic beauty is not correctly made. We will now discuss this problem in the light of Arthur Danto's comments on Matisse's Blue Nude.

Arthur Danto rightly argues that an artwork that is conceived as ugly and artistically excellent, does not 'become' beautiful due to its artistic excellence. ${ }^{16} \mathrm{He}$ thus makes a correct distinction between artistic beauty and aesthetic excellence. Still, he fails to make a proper distinction between natural, human and artistic beauty. On the one hand, he argues that the meaning of an artwork is internally related to its aesthetic qualities while in natural beauty, beauty is external to meaning ${ }^{17}$ On the other hand, Danto's aesthetics still surprisingly construes beauty along formalist lines. ${ }^{18}$ Although Danto rightly claims that we have to identify the meaning of the work as given by the thought, in order to see whether the work is beautiful, the beauty of a work seems to be limited by external factors, but cannot be positively influenced by it. ${ }^{19}$ When beauty is inappropriate to the content of the work, the artwork fails to be artistically beautiful, but beauty itself seems to be the same in nature as in art. ${ }^{20}$ In the 'Abuse of Beauty' Danto writes that Matisse's Blue Nude is possibly great, but definitely 'unbeautiful': someone who claims it is beautiful is 'talking through his or her hat. ${ }^{, 21} \mathrm{He}$ writes that:

it would be very difficult to accept the claim that Matisse's Blue Nude is at all beautiful: she is fierce and powerful and sufficiently ugly that voyeurism seems ruled out, let alone arousal - almost as if the ugliness were a sort of veil of modesty with which Matisse covered her nakedness. $^{22}$

Now, while Danto rightly contests the view that all good art is beautiful, Dada being a good example, he unjustly excludes those artworks from the realm of beauty that do possess artistic beauty. Danto disregards two important issues. First, substantive aesthetic properties are not timeless, fixed essences. What was beautiful in art in the Renaissance, is not the standard of artistic beauty in contemporary art. Our view of what pleases through balance and harmony in art has changed through the history of art. Substantive aesthetic properties in art, including beauty, can only be judged correctly by someone who properly situates a work with regard to its context of origin, including its place in the artist's oeuvre, its relation to the surrounding culture, and its connections to preceding artistic traditions. ${ }^{23}$ As discussed above, a beautiful artwork is not beautiful tout court, but beautiful in connection with a certain artistic context. Indeed, in the Renaissance era, Blue Nude could not have been described as 'beautiful', but most likely as disturbing and perverse. It must also be noted that Blue Nude could not have been made in that era. Secondly, as Nehamas rightly observes, here Danto seems to assume that being beautiful and looking good are the same. ${ }^{24}$ In real life this 
woman would perhaps not be considered beautiful. Yet we should not be assessing human beauty, but artistic beauty here: it is not about what is depicted, but rather about the depiction as a whole. Thus Danto fails to distinguish between artistic beauty and other kinds of beauty, and, as a consequence, limits the scope of artistic beauty dramatically.

\section{Conclusion}

We have argued that artistic beauty should be distinguished from aesthetic excellence and other kinds of beauty, most notably natural and human beauty. Following Zangwill's distinction between verdictive and substantive aesthetic properties, we have defended that beauty is a substantive, not a verdictive aesthetic property. This entails that neither all aesthetic merit is to be identified with beauty nor artistic beauty is to be equated with other kinds of beauty.

Properly drawing these distinctions is of paramount importance for the following reasons. (1) These distinctions allow us to assign aesthetic excellence to non-beautiful art. There is no need to include non-beautiful art within the realm of beauty in order to judge such artworks as aesthetically valuable. (2) These distinctions help clarifying why not all beauty in art counts as artistic beauty. Beauty that is incidental or contradicts the aims or content of the artwork is not artistic beauty. Thus, surface beauty in art does not necessarily imply artistic beauty or aesthetic merit. (3) Artistic beauty is not the mere representation of a beautiful thing. What is ugly in nature can be beautiful in art. These distinctions are useful for assessing the role of beauty and aesthetics in art. Within the Western history of art, beauty is an important and predominant feature of the aesthetic merit of art. Moreover, beauty is a crucial aspect in life and this does separate beauty from other aesthetic values. Still, this does not entail that beauty is a necessary feature of artistic value.

\section{Notes}

${ }^{1}$ Noël Carroll, Beyond Aesthetics (Cambridge: Cambridge University Press, 2001): 21.

${ }^{2}$ Ruth Lorand, Aesthetic Order. A Philosophy of Order, Beauty and Art (London and New York: Routledge, 2000): 288 and Nick Zangwill, The Metaphysics of Beauty (Cornell University Press, 2001).

${ }^{3}$ Nick Zangwill, 'Beauty', in The Oxford Handbook of Aesthetics, ed. Jerrold Levinson, (Oxford: Oxford University Press, 2003), 326.

${ }^{4}$ Zangwill, The Metaphysics of Beauty, 9 .

${ }^{5}$ Zangwill, The Metaphysics of Beauty, 19.

${ }^{6}$ Arthur Coleman Danto, The Abuse of Beauty. Aesthetics and the Concept of Art (Chicago and La Salle: Open Court, 2003): 60 and 95. 
${ }^{7}$ Danto, The Abuse of Beauty, 118.

${ }^{8}$ Danto, The Abuse of Beauty, 49.

${ }^{9}$ Danto, The Abuse of Beauty, 113.

${ }^{10}$ Danto, The Abuse of Beauty, 112.

${ }^{11}$ Graham McFee, 'The artistic and the aesthetic', British Journal of Aesthetics 45 (2005): 376.

${ }^{12} \mathrm{McFee}$, 'The artistic and the aesthetic', 369.

${ }^{13} \mathrm{McFee}$, 'The artistic and the aesthetic', 384.

${ }^{14}$ George Dickie, Art and the Aesthetic: an Institutional Analysis (New York: Cornell University Press, 1974): 42.

${ }^{15}$ James Shelley, 'The problem of non-perceptual art', British Journal of Aesthetics 43 (2003): 368.

${ }^{16}$ Danto, The Abuse of Beauty, 107.

${ }^{17}$ Danto, The Abuse of Beauty, 97 and 101.

18 Diarmuid Costello, 'On late style: Arthur Danto's The "Abuse of Beauty"', British Journal of Aesthetics 44 (2004): 427.

${ }^{19}$ Danto, The Abuse of Beauty, 95-96.

${ }^{20}$ Danto, The Abuse of Beauty, 121-122.

${ }^{21}$ Danto, The Abuse of Beauty, 36-37.

${ }^{22}$ Danto, The Abuse of Beauty, 114.

23 Jerrold Levinson, Contemplating Art. Essays In Aesthetics (Oxford: Oxford University Press, 2006): 316.

${ }^{24}$ Alexander Nehamas, Only a Promise of Happiness. The Place of Beauty in a World of Art (Princeton and London: Princeton University Press, 2007): 97.

\section{Bibliography}

Carroll, Noël. Beyond Aesthetics. Cambridge: Cambridge University Press, 2001.

Costello, Diarmuid. 'On late style: Arthur Danto's The "Abuse of Beauty"'. British Journal of Aesthetics 44 (2004): 424-439.

Danto, Arthur Coleman. The Abuse of Beauty. Aesthetics and the Concept of Art. Chicago and La Salle: Open Court, 2003.

Dickie, George. Art and the Aesthetic: an Institutional Analysis. New York: Cornell University Press, 1974. 
Levinson, Jerrold. Contemplating Art. Essays In Aesthetics. Oxford: Oxford University Press, 2006.

Lorand, Ruth. Aesthetic Order. A Philosophy of Order, Beauty and Art. London and New York: Routledge, 2000.

McFee, Graham. 'The artistic and the aesthetic'. British Journal of Aesthetics 45 (2005): 368-387.

Nehamas, Alexander. Only a Promise of Happiness. The Place of Beauty in a World of Art. Princeton and London: Princeton University Press, 2007.

Shelley, James. 'The problem of non-perceptual art'. British Journal of Aesthetics 43 (2003):363-378.

Zangwill, Nick. The Metaphysics of Beauty. Cornell University Press, 2001.

- 'Beauty'. In The Oxford Handbook of Aesthetics, edited by Jerrold Levinson, 325-343. Oxford: Oxford University Press, 2003.

Annelies Monseré is a fellow of the Research Foundation Flanders (FWO) at Ghent University and she is working on her $\mathrm{PhD}$ within the philosophy of art. Her research focuses on the definition and the identification of art.

Bart Vandenabeele is a professor at the Department of Philosophy and Moral Sciences at Ghent University. His research focuses on the values of (modern and contemporary) art, beauty, tragedy, the sublime, Schopenhauer, Nietzsche, and Kantian aesthetics. 